\title{
Service Delivery Toward Customer's Satisfaction: Commercial Bank of Michille Branch, Dilla Town, Southern Ethiopia
}

\author{
Mengistu Meresa \\ College of Agriculture \& Natural resources, \\ Department of Natural Resources Management, Dilla University
}

\begin{abstract}
The Study was conducted in Commercial bank of Ethiopia, Michille branch, Dilla Town.The major aim of the study was to assess the nature of service delivery towards customer's satisfaction in the selected bank because Customer satisfaction is essential for the success of service firms like Commercial bank of Ethiopia. The service delivery has become an aspect of customer satisfaction. Day by day it has been proven that service delivery quality is related to customer's real satisfaction. This study endeavors to discover the impact of service delivery towards customer satisfaction in Commercial Bank of Ethiopia, Michille Branch, Dilla Town. Five dimensions such as in service quality tangibility, reliability, responsiveness, empathy, and assurance were considered as the base for this study. Structured questionnaire and interview has been used to collect the data survey. The sample size was 100 and the data has been analyzed by using Excel program to include pie-charts, tables, graphs, percentages. The study has a significance in terms of service quality dimensions which is crucial for customer satisfaction in public/Governmental commercial banking sector in Ethiopia in general and in Michille bank in particular. The finding of the study shows that about 85 percent respondents are satisfied with Michille Bank service delivery, so that the respondents confirm that they will wait and see for changes of the study bank (Michille Bank) rather than they move to other banks.
\end{abstract}

Keywords: Commercial bank of michille; service delivery; customers' satisfaction; Southern Ethiopia.

DOI: $10.7176 /$ RJFA/12-15-04

Publication date:August $31^{\text {st }} 2021$

\section{Introduction}

Customer service and satisfaction is a crucial source of distinctive competency and often considered as key success factor in sustaining competitive advantage in service industries. Service quality has become one of the key driving forces for business sustainability and is vital for firms' accomplishment (Richins M.L., 1983). Service quality in banking implies consistently anticipating and satisfying the needs and expectations of customers (Parasuraman et al., 1985) and Zeithaml et al., (1990) noted that the key strategy for the success and survival of any business institution is the deliverance of quality services to customers. Provisions of high quality service results in higher customer satisfaction and enhance customer loyalty. Customers are the sole judge of service quality; an organization can build strong reputation for quality service when it can constantly meet customer service expectations (Saunders M., Lewis P. and Thornhill A). Thornhill A. (2012) defined Service quality as the subjective comparison that customers make between the quality of the service that they want to receive and what they actually get.

Similarly, customer satisfaction is crucial in the banking sector because of the special nature of the financial services which are characterized by intensive contacts with customers who have different needs and require customized solutions (Yamane, T. 1967), Service quality is an important antecedent of customer satisfaction which is the result of the customer's perception and the quality of the service and it is a significant predictor of customer satisfaction using SERVQUAL instruments (Saunders,M.,Lewis P. and Thornhill A., 2009). Service quality and customer satisfaction have been identified as key elements of the service-profit chain. As the perceived service quality is the key driver of perceived value, one of the determinants of success of a firm is how the customers perceive the resulting service quality, (Taylor, S.A. et al. 1993). It is the perceived value, which determines customer satisfaction. The most widely used model to measure perceived service quality known as SERVQUAL was developed by Parasuraman et al. $(1985,1988)$.

The establishment of banks in Ethiopia traces its origin to over 100 years. The agreement that was reached in 1905 between Emperor Minelik II and Mr.Ma Gillivray, representative of the British owned National Bank of Egypt, marked the introduction of modern banking in Ethiopia. Following the agreement, the first bank called Bank of Abysinia was inaugurated on Feb.16, 1906 by the Emperor. The Bank was totally managed by the Egyptian National Bank. (Richins M.L. 1983).). Within the first fifteen years of its operation, Bank of Abysinia opened branches in different areas of the country. In 1906 a branch in Harar (Eastern Ethiopia) was opened at the same time of the inauguration of Bank of Abysinia in Addis Ababa. Another Bank branch at Dire Dawa was opened two years later and at Gore in 1912 and at Dessie and Djibouti in 1920. In the new Commercial Bank of Ethiopia, in contrast with the former State Bank of Ethiopia, all employees were Ethiopians. There were two other banks in operation namely Banco di Roma S. and Banco di Napoli S.C. that later reapplied for license 
according to the new proclamation each having a paid-up capital of Eth. Birr 2 million. The first privately owned bank, Addis Ababa Bank Share Company, was established by Ethiopians initiative and started operation in 1964 with a capital of Birr 2 million in association with National and Grindlay Bank, London which had 40 percent of the total share. In 1968, the original capital of the Bank rose to 5.0 million and until it ceased operation, it had 300 staff at 26 branches.

Thus, from the finding of Newman and Cowling, the researchers understand that if service quality customer's satisfaction is going down in the organization and doesn't meet the expectation of its customers, it will have negative effects on the organization's profitability. Thus, this study, therefore, will assess customers' satisfaction on the service given by Commercial bank of Ethiopia, Michille branch, Dilla Town.

\section{Research methods}

\subsection{Research Design}

Research can be classified as exploratory, descriptive and explanatory depending on the specific purpose that the research tries to address (Saunders et al, 2012) .Exploratory research design deals with exploring in to the phenomenon (Marczyk et al., 2005). It focuses on collecting either secondary or primary data using unstructured formal or informal procedures to interpret them. Some exploratory research design includes in-depth interview, focus groups, and projective techniques. Description refers to the process of defining, classifying, or categorizing phenomena of interest. Descriptive research is useful because it can provide important information regarding the average member of a group (Marczyk et al., 2005). Specifically, by gathering data on a large enough groups of people, a researcher can describe the average member, or the average performance of a member, of the particular group being studied. Therefore, descriptive study design is used to analyze for the data collected from customers. To make those practical qualitative research methods was used to approach the study subjects.

\subsection{Data sources}

A source of data for the study was primary and secondary sources. The primary data through questionnaire was collected from staff of the Bank and Customers of the bank by using simple random sampling method. Regarding the secondary data on the banking organizations' service and other was collected through reviewing the internal newsletters and magazines, articles, books and different financial association magazines and other pertinent documents.

\subsection{Sample Size determination}

Michille bank, the study bank, has a total population of 134 including 4 managers, 30 employees and 100 daily service seeker customers (Source: manager of Michille Bank, 2019).

Finally, the sample size was determined based on the formula proposed by Glenn (1992).

Therefore the complete survey of the study was administered on 100 respondents for the major data collection through questionnaire and the ratio of respondents was decided based on the size of the three groups of the target populations. In addition to these 6 respondents were selected randomly for interview.

\subsection{Sampling Technique}

The study was used all random, purposive and systematic random sampling methods to select the samples from the population categories. The researcher decided to employ purposive to select managers because their number is limited (4) but random sampling method was done for the customers who get service in one day because it is actually impossible to access each customer for many days and their number is too many (100). On the other hand systematic random sampling was used to select the employees because their size was average (30 in number). Therefore, to select 20 sample respondents from the total 30 employees whose name was listed in the bank, the researcher used systematic random sampling method as follows.

$$
\mathrm{K}^{\text {th }}=\mathrm{N} / \mathrm{n}
$$

Where

$\mathrm{k}^{\text {th }}=$ every respondent to be selected from the list

$\mathrm{N}=$ Total employees in the Bank

$\mathrm{N}=$ The required sample sizes

$$
\begin{aligned}
& \mathrm{K}^{\text {th }}=30 / 20 \\
& \mathrm{~K}^{\text {th }}=1.5 \text { approximately }=2
\end{aligned}
$$

Therefore, every $\mathrm{k}^{\text {th }}$ ( starting from the $1^{\text {st }}$ listed name in the bank) the 20 sample employees was selected from their list found in the bank systematically using standard formula adopted from Kothari $2^{\text {nd }}$ edition (2004).

\subsection{Method of data analysis}

The collected data will be analyzed with the help of tables, graphs, charts, frequency distributions and percentages to give a condensed picture of the data. Finally the analyzed data will be interpreted based on the 
conclusions and findings.

\section{Results and Discussion}

3.1. Respondents socio-economic characteristics

Table 1. Sex of respondents

\begin{tabular}{|l|c|c|c|c|}
\hline Ro No & Item & Description & of Number respondents & percentage \\
\hline \multirow{3}{*}{1} & \multirow{3}{*}{ Sex } & Male & 60 & $60 \%$ \\
\cline { 3 - 5 } & & Female & 40 & $40 \%$ \\
\cline { 2 - 5 } & & Total & 100 & $100 \%$ \\
\hline
\end{tabular}

Source: own survey (2021)

The result shown on the table 1 , indicates that $60 \%$ of the respondents were male groups and the rest $40 \%$ were female respondents. This means the number of male respondents was greater than the female respondents. This tells us that males are more frequent customers of the bank.

Table 2. Respondent's years of relation with Michelle bank-Dilla branch.

\begin{tabular}{|c|c|c|}
\hline Customers relation with the bank (in years) & $\begin{array}{c}\text { Respondents } \\
\text { Frequency }\end{array}$ & Percent \\
\hline $1-5$ years & 90 & $90 \%$ \\
\hline $6-12$ years & 10 & $10 \%$ \\
\hline $13-18$ years & 0 & 0 \\
\hline 19 years and above & 0 & 0 \\
\hline Total & 100 & $100 \%$ \\
\hline
\end{tabular}

Source: own survey (2021)

The study bank was established in 2014. All of the study participants had experience in using the banking services of michille bank - Dilla branch for at least 6 years including the year 2019. Most of the customers $(90$ percent) have spent 1-5 years with this study bank, 10 percent have spent 1 year very recently (2019) with this bank (Table 2).

This result indicates that the bank is too young having only 6 years age span from its foundation(2014 up to 2019). According to the respondents the customers were using other private and governmental banking services before the study bank was established. After the bank had opened in 2014 all the respondents became loyal customers of the study bank (michille commercial bank Dilla-branch).

Table 3. No of respondents who used ATM card for different years in the study Bank

\begin{tabular}{|c|c|c|c|c|}
\hline Ro No & Item & $\begin{array}{l}\text { ATM card used } \\
\text { years }\end{array}$ & No of respondents who used ATM card & Percent \\
\hline & \multirow{5}{*}{$\begin{array}{l}\text { The duration } \\
\text { respondents } \\
\text { used ATM }\end{array}$} & $<1$ year & 5 & $5 \%$ \\
\hline & & $1-2$ years & 25 & $25 \%$ \\
\hline & & $3-6$ & 70 & $70 \%$ \\
\hline & & $>6$ year & 0 & $0 \%$ \\
\hline & & Total & 100 & $100 \%$ \\
\hline
\end{tabular}

Source: own survey (2021)

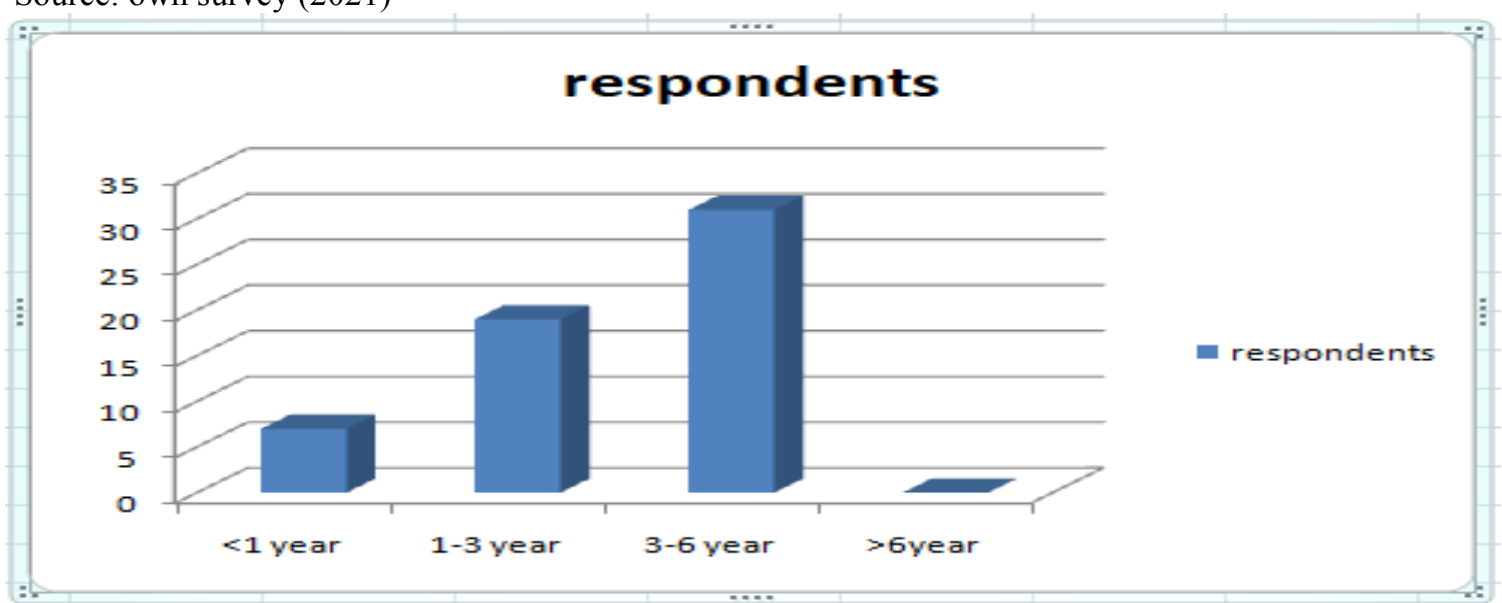

figure1. No of respondents who used ATM card in different years. source: own survey result (2021).

As one can see from table 3 and figure 1, regarding the time of respondents used ATM card, 5\% of the respondent were used ATM card for less than 1 year, and $25 \%$ of the respondents were used for $1-2$ years and the remaining most respondents 70\% were used ATM card for about 3-6 years. This implies that the majority of 
the respondents have used ATM card 3-6 years.

Table4. Using modern banking system ofMichille bank compared to other banks

\begin{tabular}{|l|c|c|}
\hline Frequency & Number of respondents & $\mathbf{\%}$ \\
\hline Very Low & 3 & $3 \%$ \\
\hline Low & 10 & $10 \%$ \\
\hline Moderate & 48 & $48 \%$ \\
\hline High & 28 & $28 \%$ \\
\hline Very High & 11 & $11 \%$ \\
\hline Total & 100 & 100.0 \\
\hline
\end{tabular}

source: own survey result (2021).

The customers' comparison of the michille banks' service with other private banks on the bases of the utilization of modern technologies by the customers revealed that the relative position of the bank as perceived by the customers is good ( moderate). Around 48 percent of the customers who took part in the study reported as the position of the bank is moderate (48 percent rated it as moderate while 10 percent rated as low) in comparison with other private banks (Table 4). Contrary to this, around 28 percent of the customers indicated as the bank is better in this regard.

Table5. Measuring waiting time by customers to get service from michille bank

\begin{tabular}{|l|c|c|}
\hline Rating & frequency & Percent \\
\hline Poor & 3 & 3 \\
\hline Satisfactory & 25 & 25 \\
\hline Good & 50 & 50 \\
\hline Very Good & 20 & 20 \\
\hline Excellent & 2 & 2 \\
\hline Total & 100 & $100 \%$ \\
\hline
\end{tabular}

source: own survey result (2021).

The rating of the bank by its relative position with other private banks in terms of waiting time by the customers participated in the study also revealed as the bank is in a good position. Out of this, around 50 percent rated the service as good compared to other banks, 20 percent rated it as very good, and 2 percent rated it as excellent, and 25 percent of the customers rated as satisfactory (Table 5). Yet, around 3 percent of the customers think that the bank is poorly performing than other banks with regard to waiting time. As indicated in Table 5, more than 25 percent of the customers reported as they are satisfied by the bank with respect to the bank's ability to meet their specific needs of services. They state some of the satisfactory drivers like employee's manner in welcoming customers, helping or guiding customers with much patience, the availability of branches and convenient working hours. Therefore, based on this result, we can conclude that customer's level of satisfaction by the banks' ability to meet their service needs is good.

\subsection{Meeting customers' expectations and performance}

Table 6. The deviation between customers' expectation and performance

\begin{tabular}{|l|c|c|}
\hline Gap & Frequency & $\begin{array}{c}\text { Valid } \\
\text { Percent }\end{array}$ \\
\hline Very High deviation & 1 & $0 \%$ \\
\hline Moderate & 58 & $58 \%$ \\
\hline Low deviation & 41 & $41 \%$ \\
\hline Very low deviation & 0 & $1 \%$ \\
\hline No deviation & 0 & $0 \%$ \\
\hline Total & 100 & $100 \%$ \\
\hline
\end{tabular}

Source: own survey result (2021).

As it is discussed in the literature review the perception level should be higher than the expectation level to create the positive perception. As to the responses of the customers participated in study, the gap between the expectation of the customers while considering to be the customers of the bank and the extent to which their expectations were realized was found to be wide. The majority of the study participants indicated as there degree of the difference between their expectations and the reality was low (41 percent) and 58 percent as moderate. On the other hand, around 1 percent of the study participants reported that the gap was very high deviation and wide (Table 
Table 7.The gap between customers' expectation and actual performance of Michille bank and its effect on their relationship

\begin{tabular}{|l|c|c|}
\hline Effect of the gap & Frequency & \% \\
\hline Yes, it affects negatively & 20 & $20 \%$ \\
\hline No, I s stayed neutral & 70 & $70 \%$ \\
\hline Yes, it affects positively & 10 & $10 \%$ \\
\hline Total & 100 & $100 \%$ \\
\hline
\end{tabular}

Source: Own Survey result (2021)

Regarding the effect of the variation, $20 \%$ of the participants reported the difference in their expectation and quality of service delivery affects negatively. While around 70 percent expressed as they were neutral, around 10 percent reported as they were stayed positive (Table 7). This result indicates that the relationship of the bank with its customers I neither negatively nor positively affects the relationship but rather it remains neutral.

Table 8. customers' put complaints to the management

\begin{tabular}{|c|c|c|}
\hline Description & frequency & Percent \\
\hline Yes & 80 & 80 \\
\hline No & 20 & 20 \\
\hline Total & 100 & $100 \%$ \\
\hline
\end{tabular}

Source: Own survey result (2021)

In view of Table 8 , the respondents were asked whether they had presented their complaints to the bank management in relation to their expectations. The result in Table 8, showed that Around 80 percent responded that they did report their complaints to the management when they have a dissatisfaction regarding service delivery. Thus, we can generalize that the low level of dissatisfaction by the customers to the management may influence the customers' satisfaction negatively and hinders themanagement capacity to improve the quality of the service they rendered.

\subsection{Complaint handling process of the bank}

Table 9. Complaint handling process of the bank

\begin{tabular}{|l|c|c|}
\hline Description & Frequency & Percent \\
\hline No response at all & 0 & $0 \%$ \\
\hline Late response & 5 & $5 \%$ \\
\hline Satisfactory response with reasonable & 30 & $30 \%$ \\
\hline Quick response & 50 & $50 \%$ \\
\hline quick and positive response & 15 & $15 \%$ \\
\hline Total & 100 & $100 \%$ \\
\hline
\end{tabular}

Source: Own survey result (2021)

Complaint is one way of getting feedback for management and handling complaints on time very wisely is one of the management responsibilities (Saunders M., Lewis P. and Thornhill A., 2012). In view of this, most of the study participants expressed as they did get response in time. Moreover, most of those who got the responses reported as the response were satisfactory, in time and positive. In connection to this, 50\% percent of the customers indicated as the response was quick and positive, 30 percent indicated as the response was satisfactory in addressing their concern, and 15 percent indicated as the response was quick and positive response (Table 9). However, from this point of view, it is possible to conclude that Complaint handling process of the bank is quick response to satisfy its customers.

Table 10. Willingness to continue being customer of the study organization (michille bank)

\begin{tabular}{|c|c|c|}
\hline Customers willingness to continue with Michille bank & Frequency & Percent \\
\hline No, I will not & 1 & $1 \%$ \\
\hline Yes, but will work with others too & 4 & $4 \%$ \\
\hline Yes, I will wait and see for changes & 85 & $85 \%$ \\
\hline Yes, I will keep my loyalty & 10 & $10 \%$ \\
\hline Total & 100 & $100 \%$ \\
\hline
\end{tabular}

Source: Own survey result (2021)

As a proxy indicator of the customers' satisfaction as well as a measure of the customers' commitment, the customers who participated in the study were asked if they are intending to continue being the bank's customers (Richins M.L., 1983). Most of the study participants (85 percent) asserted as they will continue being the customers of michille Bank. 1 percent of the respondent customers indicated as he/she is not willing to continue with the bank due to his/her personal reason,10 percent of the respondent declared their loyalty for michille banking service (Table 10). In order to make sure that maxim 'Doing Best What Matters Most' is observed, the gaps between importance and satisfaction were analyzed for each domain. The key to customer satisfaction is 
'Doing Best What Matters Most' to customers. In other words satisfaction should be highest in the areas that are priorities for customers. This result tells us that these 'quick wins' are an excellent way to bring rapid improvement in customer satisfaction.

\section{Summary \& conclusion \\ Summary}

From the data collected, analysis had made in order to measure the level of customer satisfaction with service delivery in commercial bank of Ethiopia, Michille Bank branch, Dilla town location using Graphs, charts, figures and percentages. To clearly asses the gap between customer expectation and perception in the service quality provided by Michille Bank and other related objectives mentioned earlier, the study put the following as its summary of findings. After analyzing the information gathered through structured questionnaires, the following major findings are presented:-

1. About 85 percent respondents are satisfied with Michille Bank service delivery while the remaining $15 \%$ was not satisfied.

2. As revealed in the frame work analysis customers' rankedthe five service delivery dimensions as empathy, assurance and reliability of the bank were found to be the drivers of the customer satisfaction.

3. The customers of the bank have higher expectations than what they actually receive fromthe bank even though the gap is not very high.

4. As seen from the analysis most of the respondents are customers of other private and government banks, so that they have a chance to compare the service of Michille Bank bank from the other.

5. Around 48 percent of the customers who took part in the study reported as the position of the bank are ranked as moderate.

6. In connection to response ability of the study bank, $50 \%$ percent is positive

7. Around $85 \%$ of the respondents confirm that we will wait and see for changes of the study bank (Michille Bank) rather than they move to other banks.

\section{Conclusion}

Satisfied customers are a good work of mouth communicators for an organization and will stay longer. In the contrary customers are difficult to retain and create a negative impact in attracting the new ones (RahimMosahab, Osman Mahamad, T. Ramayah, 2010),From the overall findings in relation this research it can be concluded that commercial bank of Ethiopia, Michille branch customers perceived that the bank's service delivery was above their expectation in all service issues. We can conclude form the findings that around 85 percent of the customers are satisfied with the service delivery of Michille Bank. But the remaining 15 percent are not satisfied with the service delivery which in turn has a negative impact on the banks competitiveness in the black market. The findings of the research also indicate that the study bank should work in all the service quality dimensions and in addressing customer's feedback to be competitive in the market. Despite the differences in the result of the dimensions, the bank management should give attention to all the five SERVQUAL dimensions and tangibility and responsiveness needs special attention of the management. Generally, to outreach the markets it is very important to the bank to improve in all the five service delivery dimensions and provide quality service that will satisfy its customers in order to keep its values and attain its vision to be the strongest and most preferred Bank of the People.

\section{Acknowledgement}

Our deepest gratitude goes to commercial bank of Ethiopia, Dilla Town branch for their support in providing necessary documents and reports during the research process, insightful comments and constructive advices. The successful accomplishment of this article would have been very difficult without support. Next, we would also like to express our heartfelt gratitude to Dilla University for his valuable assistance for the development, improvement and complete of this manuscript.

\section{Declaration}

I, hereby declare that this article work entitled as "Service delivery toward customer's satisfaction: commercial bank of Southern Ethiopia, Michille Branch, Dilla Town." is my original work and has not been published by/in any other local or international publishers, and that all sources of materials used for the study have been fully acknowledged.

Declared by: Mengistu Meresa

\section{References}

Rahim Mosahab, Osman Mahamad, T. Ramayah(2010), Service Quality, Customer Satisfaction and Loyalty: A Test ofMediation, Vol. 3, No.4 
Richins M.L. (1983). Negative Word-of-Mouth by dissatisfying Customers: A Pilot Study, Journal of Marketing, Vol. 47

Richins M.L. (1983). Negative Word-of-Mouth by dissatisfying Customers: A Pilot Study, Journal of Marketing, Vol. 47

Saunders M., Lewis P. and Thornhill A. (2012), Research Methods for Business Students.6thed. Pearson Custom Publishing

Saunders, M., Lewis P. and Thornhill A. (2009).Research Methods for business students4th ed. Pearson education limited.

Saunders,M.,Lewis P. and Thornhill A.(2009). Research Methods for business students4th ed. Pearson education limited.

Taylor, S.A., Sharland, A., Cronin, A.A. Jr., and Bullard, W. (1993).Recreational Quality in the International Setting, International Journal of Service Industries Management

Yamane T. (1967), Statistics an Introductory Analysis, 2nded. New York, Harper and Row

Zeithaml Valarie A. and Mary Jo Bitner (2003), Services Marketing, 3rd ed. New Delhi: Tata McGraw-Hill Companies, Inc

Zeithaml Valarie A. and Mary Jo Bitner (2003), Services Marketing, 3rd ed. New Delhi: Tata McGraw-Hill Companies, Inc. 